\title{
The Study of Sensitivity of the Black Sea Hydrophysical Fields Reanalysis Results to the Applied Atmospheric Forcing
}

\author{
L.I. Sukhikh, V.L. Dorofeyev \\ Marine Hydrophysical Institute RAS, Sevastopol, Russian Federation \\ e-mail: l.sukhikh@gmail.com
}

\begin{abstract}
The results of two reanalyzes of the Black Sea hydrophysical fields based on the remote sensing data (2000-2012) assimilation are compared. The simulations are carried out using different arrays of the atmospheric fields, namely ERA-Interim and MM5.

It is shown that the results of both computations are quite close due to significant impact of the assimilated data. At the same time, there are some differences in the temperature, salinity and current fields. In particular, it is shown that temperature difference in the subsurface layer of the Black Sea is caused by the corresponding difference of the heat fluxes on the free sea surface in the atmospheric data. At that, salinity difference in the subsurface layer is to a greater extent determined by the difference of the wind stress vorticity than by the fresh water fluxes through the sea surface. It is shown that the currents simulated using the MM5 atmospheric data are more intensive, especially for the time scales shorter than a month. It is stipulated by a better spatial-temporal resolution of the MM5 fields. This difference in the current intensity is mainly due to the wind stress field. In both calculations the basic contribution to the vertical circulation cell formation in the Black Sea upper layer is done by wind forcing.
\end{abstract}

Keywords: reanalysis, the Black Sea dynamics, numerical modeling, data assimilation, remote sensing.

DOI: 10.22449/1573-160X-2016-5-45-60

(C) 2016, L.I. Sukhikh, V.L. Dorofeyev

(C) 2016, Physical Oceanography

Introduction. Sea and ocean environment monitoring is one of the most important scientific problems of rational environmental management. In recent times modern achievements in the field of mathematical modeling and observational data assimilation methods are actively applied to investigate the behavior of marine systems. It is known that when modeling the sea water dynamics, atmospheric effect (whose fields are used as boundary conditions at a free surface) plays an important role. Scientific centers on atmosphere monitoring and forecasting nowadays produce a plenty of datasets characterizing the ocean atmosphere interaction. Mostly these are the results of retrospective atmosphere analysis. As a rule, the researches undertaking numerical modeling of the sea and ocean dynamics chose one or another dataset according to their own criteria. The results of such researches will depend on the applied atmospheric effect. Such dependence is especially strong for the enclosed seas where the effect of lateral boundaries on water properties is comparatively small, unlike the basins with open lateral boundaries. The example of such basins is the Black Sea which is connected with the Mediterranean Sea by the system of narrow straits. The Black Sea is one of the largest enclosed seas in the world and it has its own unique ecosystem. The coastal line of the Black Sea basin is relatively simple with no large gulfs or islands. The maximum depth of the Black Sea makes up a bit more than $2 \mathrm{~km}$. Because of closureness and small size the Black Sea has lower (as compared to the 
oceans) thermal inertia and, as a consequence, it is more dependent on the changes of atmosphere characteristics.

Recently, several works on the Black Sea physical reanalysis had been carried out. In particular, in the papers [1 - 3] hydrophysical fields on the regular grid were obtained on the basis of different models of the Black Sea circulation and hydrological temperature and salinity measurements. Time period (for which the reanalysis was carried out) covers more than 30 years: from 1971 to early 90-ies. Its choice is due to the fact that the period contains the maximum amount of largescale hydrological surveys performed in the Black Sea water area. In [4] the results of the Black Sea physical field reanalysis for 1993 - 2012 period are represented. The feature of the given paper is satellite data usage for assimilation (along-track anomalies of the sea free surface elevation and surface temperature). The fields obtained by ERA-Interim (ECMWF) atmospheric reanalysis were used as atmospheric effect. In order to assess the impact of the chosen atmospheric effect on the hydrophysical fields obtained as a result of reanalysis, the calculation repeating the one considered in [4] (but with other set of atmospheric parameters) in the given investigation was performed. The given paper, where we compare the results of two calculations, is devoted to the research of the Black Sea hydrophysical field reanalysis result sensitivity to the applying atmospheric effect.

Reanalysis scheme. The scheme of reanalysis carried out in this paper is represented in [4]. Its main elements are numerical hydrodynamic model adapted for the basin under consideration, measurement data and an algorithm of their assimilation in the model. The Black Sea circulation model [5] developed in Marine Hydrophysical Institute and based on approximation of system of primitive ocean dynamics equations (then it was modified and applied in the working nowcasting - forecasting model of the Black Sea hydrophysical fields [6]) was taken as a basis.

Spatial step of the model grid makes up $4.8 \mathrm{~km}$ and this provide adequate description of synoptic processes. Vertical discretization is performed by means of 35 computational levels compressed towards the sea surface. Vertical turbulent diffusion and viscosity are parameterized by the coefficients that depend on depth and time. Time dependence is of climatic character, i. e these coefficients vary within an annual cycle. In the estuaries of rivers and straits there were set normal velocity components (corresponding to monthly average climatic values of discharges). Moreover, at the sections of lateral boundary where the water got into the computational domain (river estuaries and lower Bosphorus current) the salinity values were set.

The fields of atmospheric parameters were used as boundary conditions at the free sea surface. As it was mentioned above, in [4] there were used the results of ERA-Interim (ECMWF) atmospheric reanalysis: near-surface wind, heat and fresh water fluxes, solar radiation. Initially these fields had $0.75^{\circ}$ spatial resolution and their discreteness by the time made up one day. In the given paper a comparison of physical reanalysis results from [4] with the Black Sea hydrophysical fields obtained using a regional atmospheric reanalysis (performed according to $M M 5$ model [7]) with $0.2^{\circ}$ spatial resolution in a zonal direction and $0.15^{\circ}$ in meridional one and with $1 \mathrm{~h}$ discreteness by the time is represented. 
An assimilation of observational data is an important element of reanalysis. In the given investigation the same datasets as in [4] (sea surface temperature (SST), free surface elevation anomalies and mean annual profiles of temperature and salinity) were assimilated. Sea surface temperature was taken from GHRSST and NODC (1993 - 2009) archives and for the last period (2010 - 2012) - from OSI $T A C$ archive. In order to assimilate altimetry measurements all available satellite data for the reanalysis period (NASA, AVISO and SL TAC archives) were used. Temperature and salinity annual average profiles were prepared on the basis of all hydrographic surveys and floating buoy data for the considered period.

Algorithm of sea surface temperature assimilation is similar to the one described in [8]. At the grid points where SST data are available measured temperature values are compared with model ones. Then, at the measurement points at the horizons of the model within the upper mixed layer the sources in the right part of transport - diffusion equation, proportional to the temperature values discrepancy, are being plugged in.

Satellite altimetry data were assimilated in the circulation model according to the algorithm presented in $[9,10]$. Briefly it can be described in a following way: temperature and salinity profiles are corrected in each point proportionally to the difference between the measured free surface elevation value and the model one. Weight coefficients (depending on depth) are calculated by cross-covariance functions of level errors and temperature or/and salinity.

Depth average temperature and salinity values were corrected at the horizons below $200 \mathrm{~m}$ in accordance with average annual profiles obtained from contact measurement data on which the climatic seasonal variation was imposed.

The analysis of the results. The data of atmospheric reanalysis carried out on the basis of MM5 regional atmospheric model cover 2000 - 2012 period, therefore hydrophysical field calculation performed on their basis is restricted by the mentioned time interval. Consequently, the comparison of results of two Black Sea hydrophysical field reanalyzes was carried out for the same time period. Subsequently, for brevity we will denote the reanalysis the results of which are described in [4] using ERA-Interim atmospheric data as $\mathrm{C} 1$, and the reanalysis where $M M 5$ atmospheric reanalysis was applied as C2.

At first we are to consider the difference in temperature regime of the Black Sea surface layer by the results of two calculations. For this aim we will analyze temperature values (averaged over the month and over the basin area) for the sea surface as well as for $0-30 \mathrm{~m}$ and $30-100$ layers. Sea temperature obtained in each calculation depends on the data under assimilation and on the heat fluxes that are specified as boundary conditions on the surface (on the lateral boundaries heat fluxes are absent). In both reanalyzes the same surface temperature satellite data sets were applied, so it may be assumed that the temperature difference in the surface layers of the sea is mainly due to the difference of heat quantity that incomes through the free surface. (Temperature difference can be also affected by the difference in the sea upper layer circulation obtained in each calculation). In Fig. 1, $a$ together with the graph of SST mean values difference the graph of heat fluxes difference on the free surface (ERA-Interim and MM5), which are averaged in the same way as SST, is also depicted. It is clearly evident from the graph that 
the temperature difference in different layers of the Black Sea has interannual and interseasonal variability. The range of oscillations for temperature in the surface layer and upper $30 \mathrm{~m}$ one reaches $0.6^{\circ} \mathrm{C}$. Sea surface temperature (Fig. 1, a) is higher during the period from the middle of the year and to the late winter of next year according to P1 calculation. During a relatively short period in spring-summer season SST is always lower according to C1 computation than in accordance with C2 one, but in 2011 the results of both calculations were close. The difference of mean surface temperature correlates well with the one of heat fluxes on the free sea surface at that. That means that temperature difference in the near-surface layer is determined by the difference of heat fluxes incoming through the surface
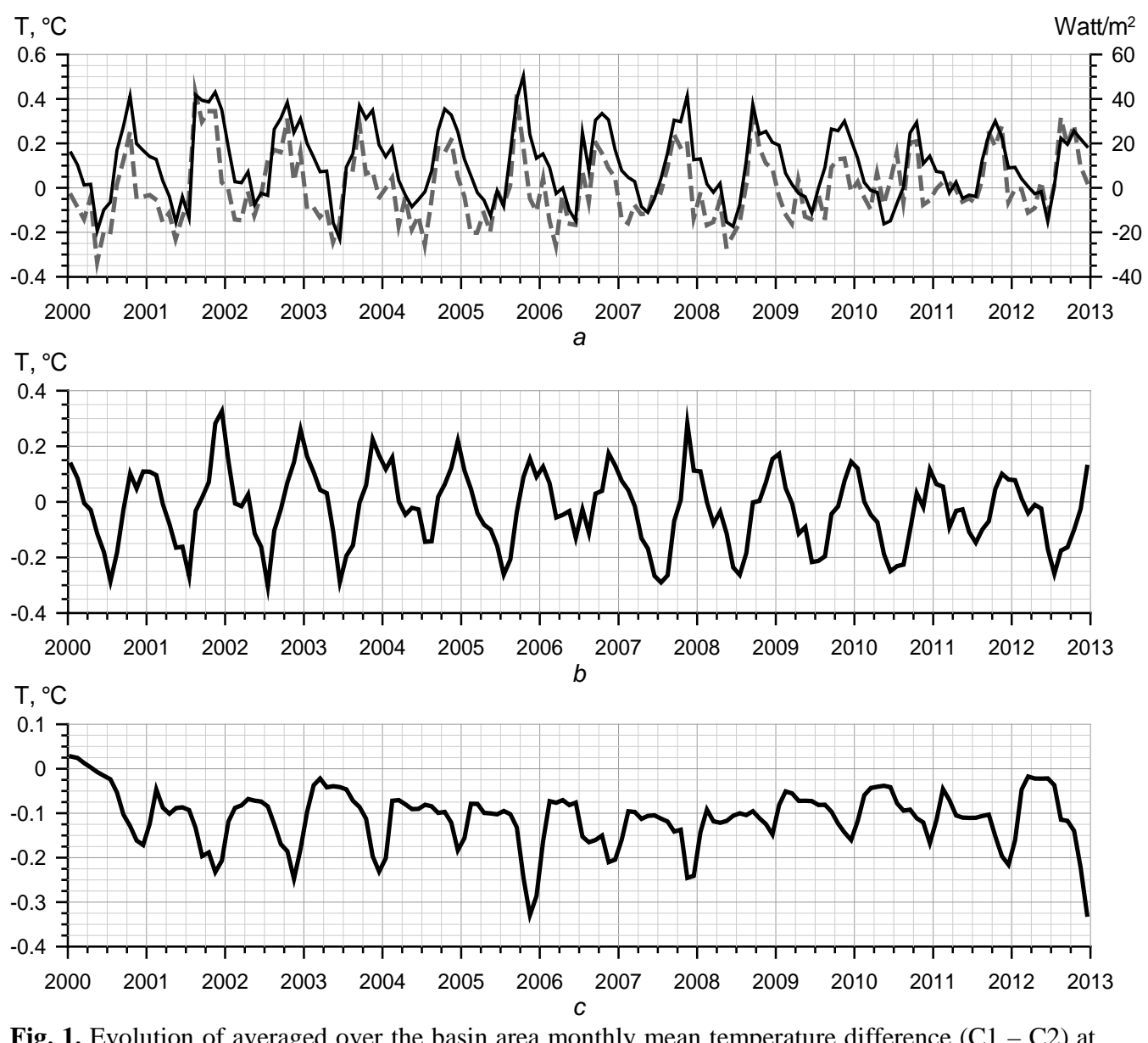

Fig. 1. Evolution of averaged over the basin area monthly mean temperature difference $(C 1-C 2)$ at the sea surface $-a$, in $0-30 \mathrm{~m}$ layer $-b$, in $30-100 \mathrm{~m}-c$, and also the difference of heat fluxes at free sea surface (dashed line in $a$ section).

The curve of temperature difference variability in $0-30 \mathrm{~m}$ layer (Fig. $1, b$ ) is qualitatively close to the behavior of surface temperature in Fig. 1, $a$. The difference between them consists in the length of periods with positive and negative values of temperature difference during the year. In $0-30 \mathrm{~m}$ layer the 
duration of time period when this difference is positive (three month at the end of the year and three month in the beginning of the next year) is approximately equal to the duration of period when it is negative.

In $30-100 \mathrm{~m}$ layer the behavior of temperature difference is unlike the one observed near the surface. According to $\mathrm{C} 1$ computation, temperature is lower for all years and seasons (except for the beginning of 2000), whereas the maximum variations are always observed at the end of the year. The range of variations significantly changes from year to year. The considered $30-100$ m layer in the Black Sea is characterized by the fact that it mainly consists of the cold intermediate layer (CIL). As is known (e.g. [10 - 12]), CIL waters renew themselves during the winter-spring period. In accordance with Fig. 1, $a$, the value of total heat flux at free sea surface is lower for ERA-Interim fields during this period. As a result, according to C1 computation surface waters cool down more rapidly than according to $\mathrm{C} 2$ computation. Therefore, more cold water gets into the CIL and this can be seen in Fig. 1, $c$.

It is possible to illustrate the variation of temperature values (averaged over a basin area) in upper $200 \mathrm{~m}$ layer with time by means of time diagrams given in Fig. 2. In this figure the behavior of mean temperature according to results of $\mathrm{C}$, C2 computations and their difference are represented. CIL cores (the areas highlighted with dark color that contain cold water with the temperature below $8{ }^{\circ} \mathrm{C}$ ) are clearly observed in both diagrams that demonstrate temperature change according to the results of calculations. In summer lower boundary of the layer with cold water reaches, on average, the depth of $\sim 75 \mathrm{~m}$. During almost all considered period the CIL was a bit weaker according to C2 computation. During 2000 - 2012 period no significant warming of near-surface waters was observed, unlike 1993 - 2012 period when a trend towards warming [4] was evident. As it can be seen in Fig. 2, c, the greatest variations are observed in upper $100 \mathrm{~m}$ sea layer. According to $\mathrm{C} 1$ computation, the temperature in near-surface layer is higher from the middle of summer to the spring of the next year. Moreover, the depth of the layer with positive temperature anomalies increases from minimum value (almost on the surface) in the middle of summer to $50 \mathrm{~m}$ in the beginning of the next year. However, for the spring period the temperature in this layer is lower according to $\mathrm{C} 1$ computation. In accordance with C1 computation, at a depth of more than $50 \mathrm{~m}$ sea temperature is lower for almost the entire period under consideration.

Quantitative characteristic of CIL thickness may be its volume. Mean values of CIL thickness for summer season in the Black Sea deep part obtained on the basis of results of two calculations are represented in Fig. 3. The values of CIL volumes calculated by C1 and C2 reanalysis results are rather close for summer seasons of 2000, 2009 and 2012. In other years of considered period CIL volume was significantly greater according to C1 computation than in accordance with C2 one. For 2005, 2006 and 2008 years the difference could reach from 2000 to $3000 \mathrm{~km}^{3}$. Greater CIL volume obtained by C1 computation confirms the fact that water temperature in $30-100 \mathrm{~m}$ layer is lower for this case (Fig. 1, c)

PHYSICAL OCEANOGRAPHY NO. 5 (2016) 

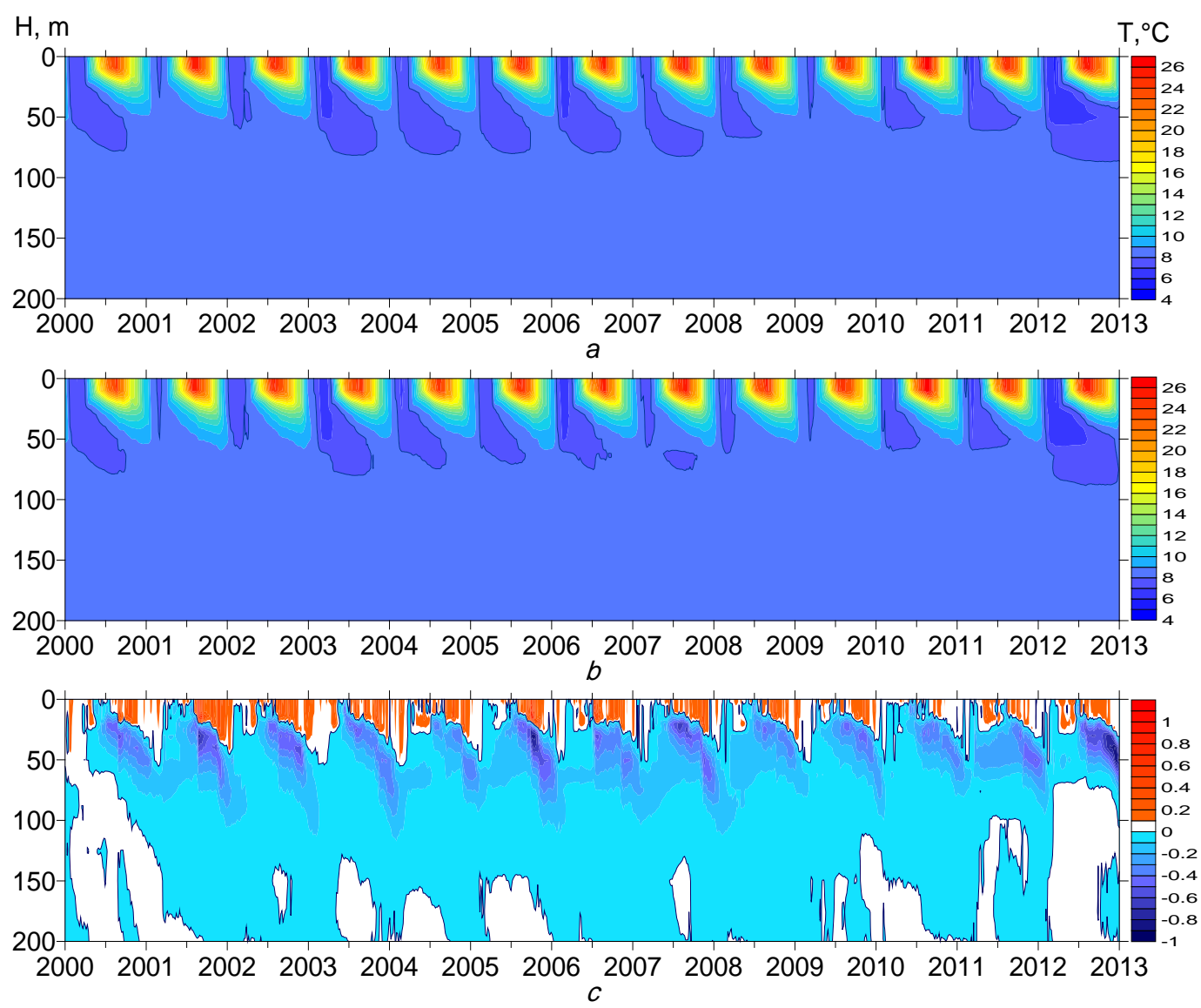

Fig. 2. Temporal evolution of monthly mean temperature values averaged over the basin area in upper $200 \mathrm{~m}$ layer according to results of $\mathrm{C} 1-a$, and $\mathrm{C} 2-b$, reanalyzes, and also their difference (C1 $-\mathrm{C} 2)$ $-c$

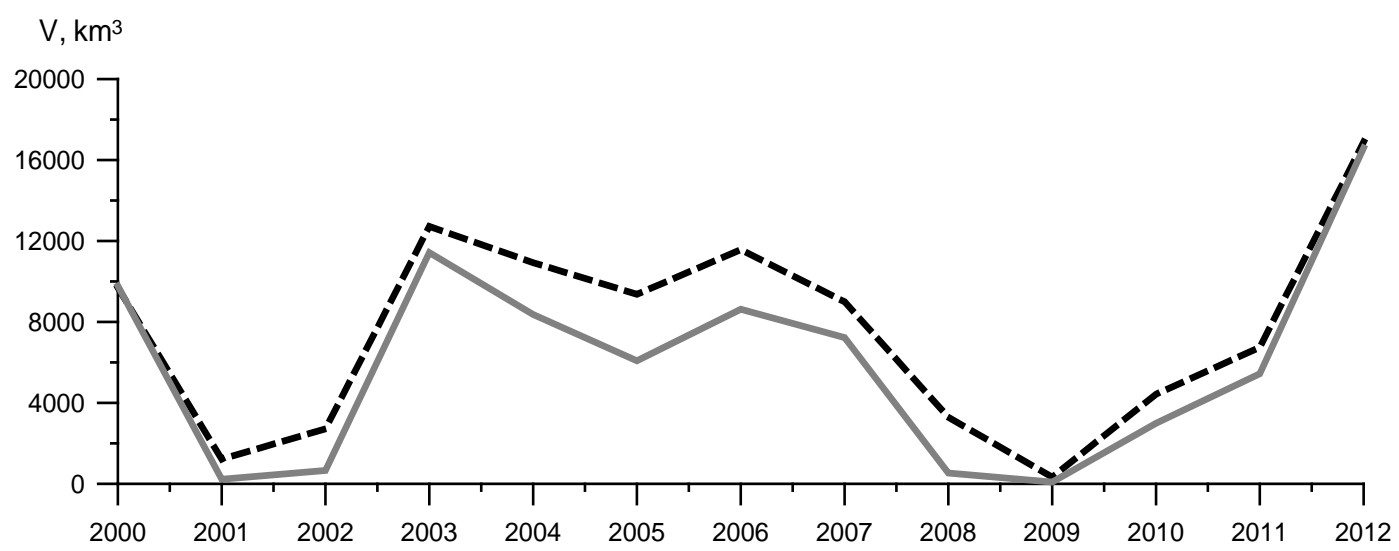

Fig. 3. Mean summer values of CIL volume in the Black Sea deep part (dashed line corresponds to C1 computation, straight line $-\mathrm{C} 2$ ) 
Salinity. In order to assess the differences of salinity fields obtained by the results of two calculations under consideration, we are to analyze monthly mean values averaged over area. Evolution of salinity distribution in upper $200 \mathrm{~m}$ layer of the Black Sea according to the data of P1 and P2 reanalyzes, as well as the difference between them, are represented in Fig. 4.
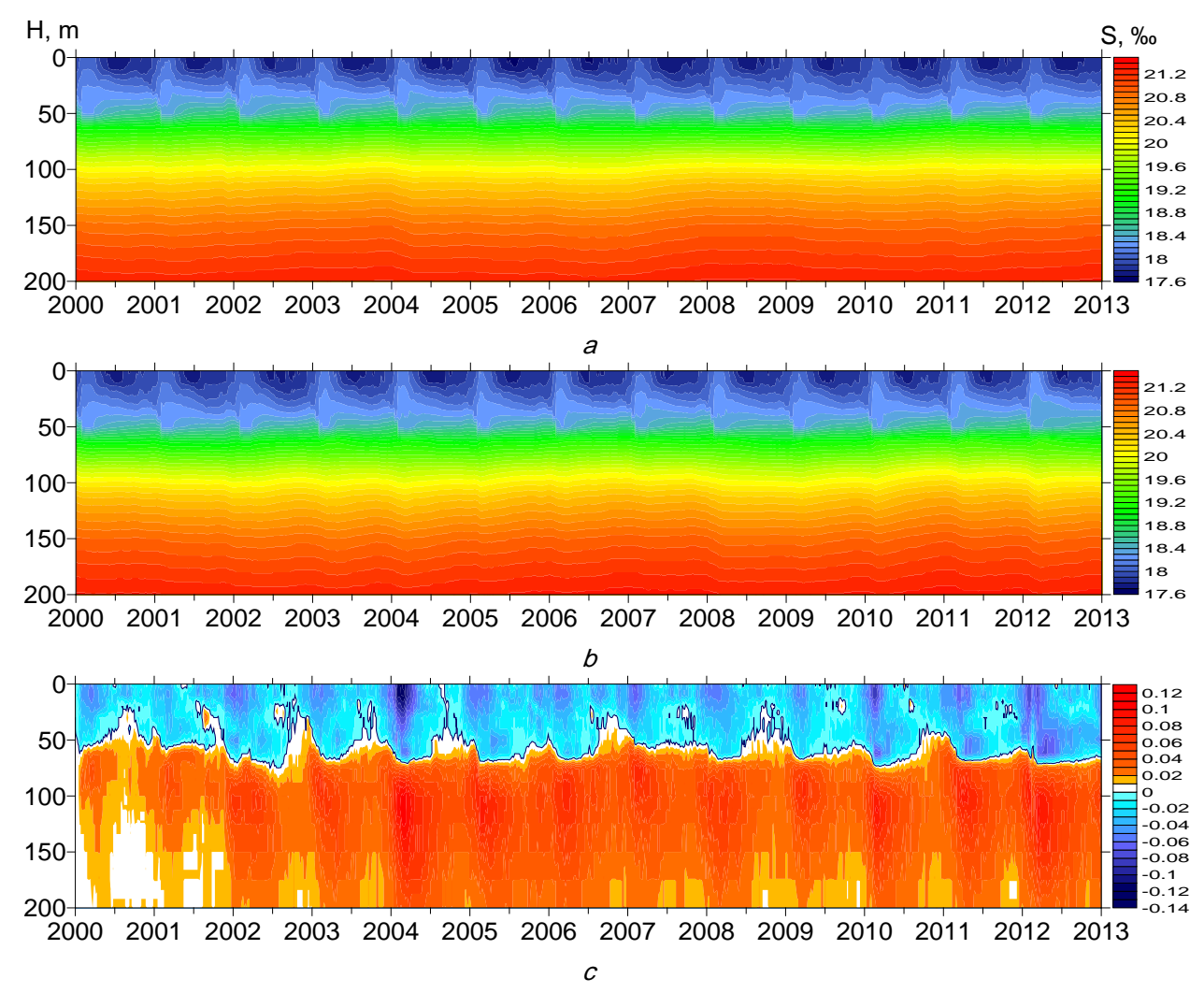

Fig. 4. Temporal evolution of monthly mean salinity values (averaged over the basin area) in upper $200 \mathrm{~m}$ layer according to results of $\mathrm{C} 1-a$ and $\mathrm{C} 2-b$, reanalyzes as well as their difference (C1 C2) $-c$

In two upper diagrams the same pattern is observed. Seasonal variability of salinity can be clearly observed down to $\sim 50 \mathrm{~m}$ depth. In the diagram of differences it is evident that in the Black Sea near surface layer salinity value is almost always higher according to C2 reanalysis, and below this layer down to 200 $\mathrm{m}$ depth the pattern reverses - the salinity of waters obtained by $\mathrm{C} 1$ reanalysis is always higher.

The differences of mean salinity values on the surface, in $0-30$ layer and in $30-100$ m layer are represented in Fig. 5. In upper sea layer salinity depends on series of factors including fresh water fluxes getting through the free surface. Only atmospheric effect fields were different for two calculations under consideration, so one may assume that differences in surficial salinity may be caused mainly by the difference of fresh water fluxes at the sea surface. In Fig. 5, $a$ in addition to surficial salinity difference the differences of monthly mean evaporation values

PHYSICAL OCEANOGRAPHY NO. 5 (2016) 
(averaged over the basin area) minus precipitation over the Black Sea area for two sets of atmospheric fields are represented.

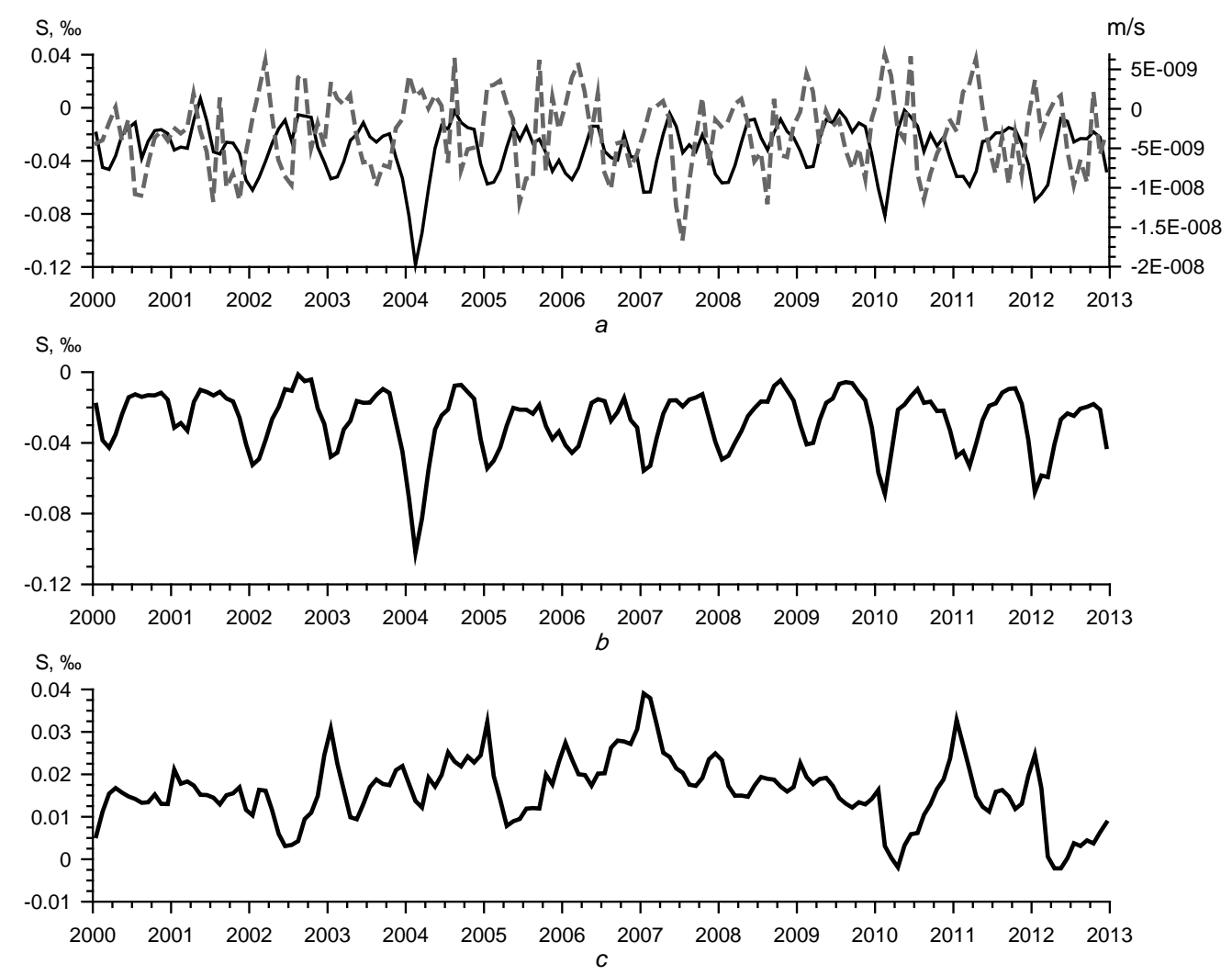

Fig. 5. Evolution of monthly mean salinity difference averaged over the basin area (P1 - P2) at the sea surface $-a$, in $0-30 \mathrm{~m}$ layer $-b$, in $30-100 \mathrm{~m}$ layer $-c$, and difference of fresh water fluxes at a free surface of the sea (dashed line in $a$ section)

On the surface and in $0-30 \mathrm{~m}$ layer the salinity value (average for the entire basin) obtained from C1 computation is lower for all years and seasons. The summer 2001 is an exception for surface salinity. The greatest variations are observed in winter season. The maximum variation of surface salinity which made up $0.12 \%$ took place in winter 2014. In summer seasons the salinity values at the sea surface and in near-surface layer obtained by the both simulations are, on average, equal. In $30-100 \mathrm{~m}$ layer salinity anomalies are small and they make up hundredths of psu. The salinity obtained by C1 computation is higher at that. Fresh water fluxes getting through the Black Sea surface are negative during almost the entire year, i.e. evaporation exceeds precipitation except for a short period at the beginning of the year. The values of these fluxes for $M M 5$ are higher except for a short time period. Thus, more intensive evaporation in $M M 5$ leads to the fact that surficial salinity in C2 reanalysis appears to be higher.

Circulation. The Black Sea upper layer circulation is predominantly of cyclonic character and this is mainly due to the positive value of wind field vorticity over the region. The pattern of circulation in winter qualitatively differs 
from the one in summer. In winter the circulation with pronounced Black Sea Rim Current (BSRC), sometimes accompanied by anticyclonic eddies on its periphery, is typical. As a rule, in summer the circulation in the Black Sea breaks up into a set of eddies [13 - 16]. In summer season the intensity of currents is lower than in winter. It is represented in [4] that such sea current behavior is caused primarily by the value of atmospheric air cyclonic vorticity over the Black Sea basin. The examples of currents in upper $30 \mathrm{~m}$ layer of the Black Sea for January and July 2008 obtained by C1 and C2 reanalyzes are given in Fig. 6.
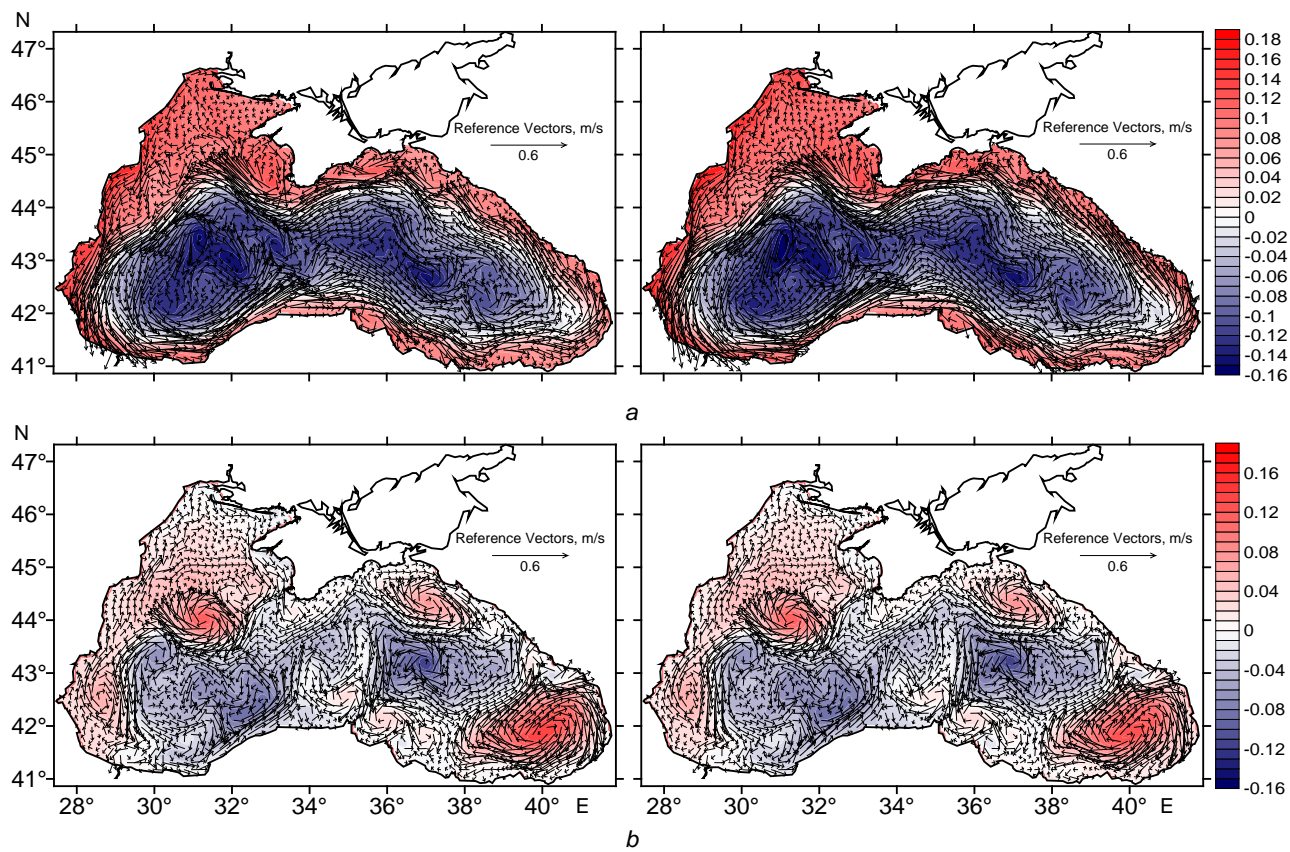

Fig. 6. The maps of mean currents in upper $30 \mathrm{~m}$ layer of the Black Sea for January $-a$, and July $-b$, 2008 (on the left - according to C1 reanalysis, on the right - according to C2 reanalysis)

According to both sets of data, upper layer circulation is almost identical for both winter and summer, although there are minor differences. Such similarity of current maps is associated with the fact that the obtained circulation is strongly affected by altimetry assimilation that was the same in both calculations. Further, for qualitative comparison of results by horizontal circulation we are to select kinetic energy density (averaged over area) of currents in upper layer as a parameter.

The graphs of variation of kinetic energy density (averaged over the Black Sea basin area) of monthly mean circulation in upper $30 \mathrm{~m}$ layer according to C1 and C2 results are represented in Fig. 7, $a$. Throughout the time interval both graphs are close to each other. The maximum values of kinetic energy are observed in winter. At the same time, kinetic energy density values differ the most. This difference in current intensity is determined mainly by the fields of wind stress which were 
applied as boundary conditions for momentum flux at free sea surface. Current kinetic energy variation graphs which are the deviation from monthly average values (an analogue of oscillatory motions in the theory of turbulence) are given in Fig. $7, b$. For these currents kinetic energy density values are significantly lower according to $\mathrm{C} 1$ computation than according to C2 one. This is caused by the fact that wind fields applied in C2 reanalysis have higher spatial and temporal resolution. Correspondingly, the intensity of rapidly changing currents is higher in this case.
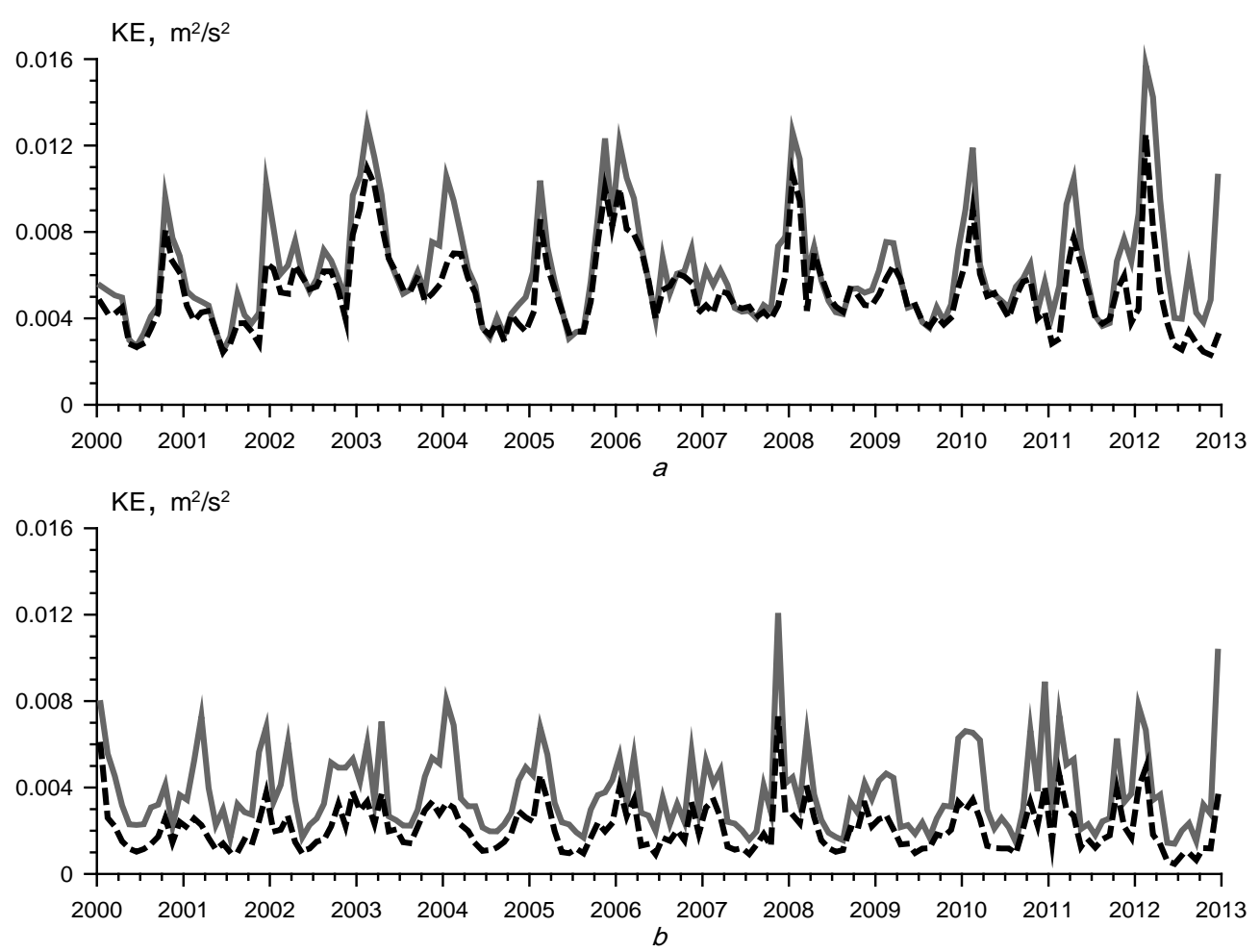

Fig. 7. Temporal evolution of monthly mean kinetic energy density of currents in $0-30 \mathrm{~m}$ layer (dashed line corresponds to C1 results, solid line - to C2 results) - $a$; graphs of current kinetic energy deviation from monthly mean values (dashed line corresponds to C1 results, solid line - to C2 results) $-b$

For the development of circulation in the Black Sea upper layer two wind field characteristics are very important: its intensity and vorticity value. For two cases under consideration monthly average fields of wind stress were calculated and amplitude and vorticity averaged over the basin area were determined by them. In Fig. 8 the graphs of variation of current kinetic energy density difference $(E(C 1)$ $E(C 2))$ for two data sets together with the difference of wind field amplitude and vorticity (averaged over the area), which were applied when performing the corresponding reanalysis, are represented. 
Kinetic energy density is almost always lower according to C1 than according to C2, especially in winter. Their difference practically does not depend on wind field intensity difference at that (Fig. 8,a). At the same time circulation intensity difference correlates well with the one of wind vorticities averaged over the area. Thus, in spite of the fact that the Black Sea upper layer circulations obtained in two calculations are rather close, there are significant differences in their intensity. Besides, they are caused by the difference of wind field vorticities used in these calculations.
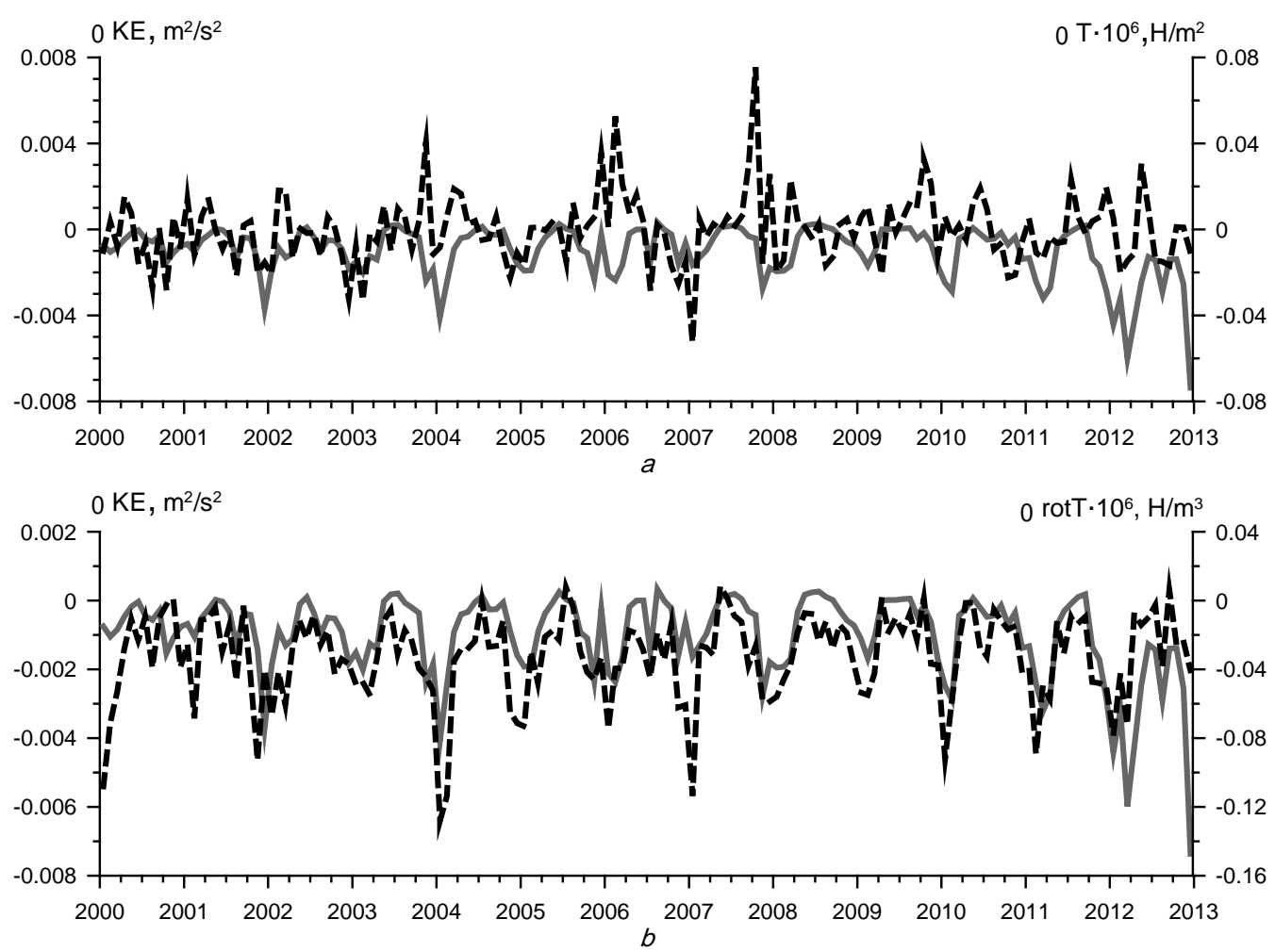

Fig. 8. Graphs of variation of monthly average values of current kinetic energy density (solid line); difference of averaged over the area wind field amplitude $(a)$ and vorticity $(b)$ (dashed line)

Now we are to compare vertical circulation obtaining in each case. On average, in the center of the basin in its deep part water rises up to the surface, near the surface it moves towards the shore and then it gets down. Such pattern of vertical circulation in the upper layer is determined by cyclonic character of currents in the Black Sea. In the paper [4] the fact that wind effect makes the main contribution to the formation of vertical circulation cell in the Black Sea upper layer is represented. Average vertical velocity profiles (from 0 to $200 \mathrm{~m}$ ) calculated by the results of $\mathrm{C} 1$ and $\mathrm{C} 2$ reanalyzes for two parts of the Black Sea basin: for the deepwater area (below $1000 \mathrm{~m}$ ) and for the remaining part located above continental slope and shelf, are given in Fig. 9, $a, b$. The profiles were obtained by averaging over the area (bounded by $1000 \mathrm{~m}$ isobath) and the time for the entire period under consideration. 


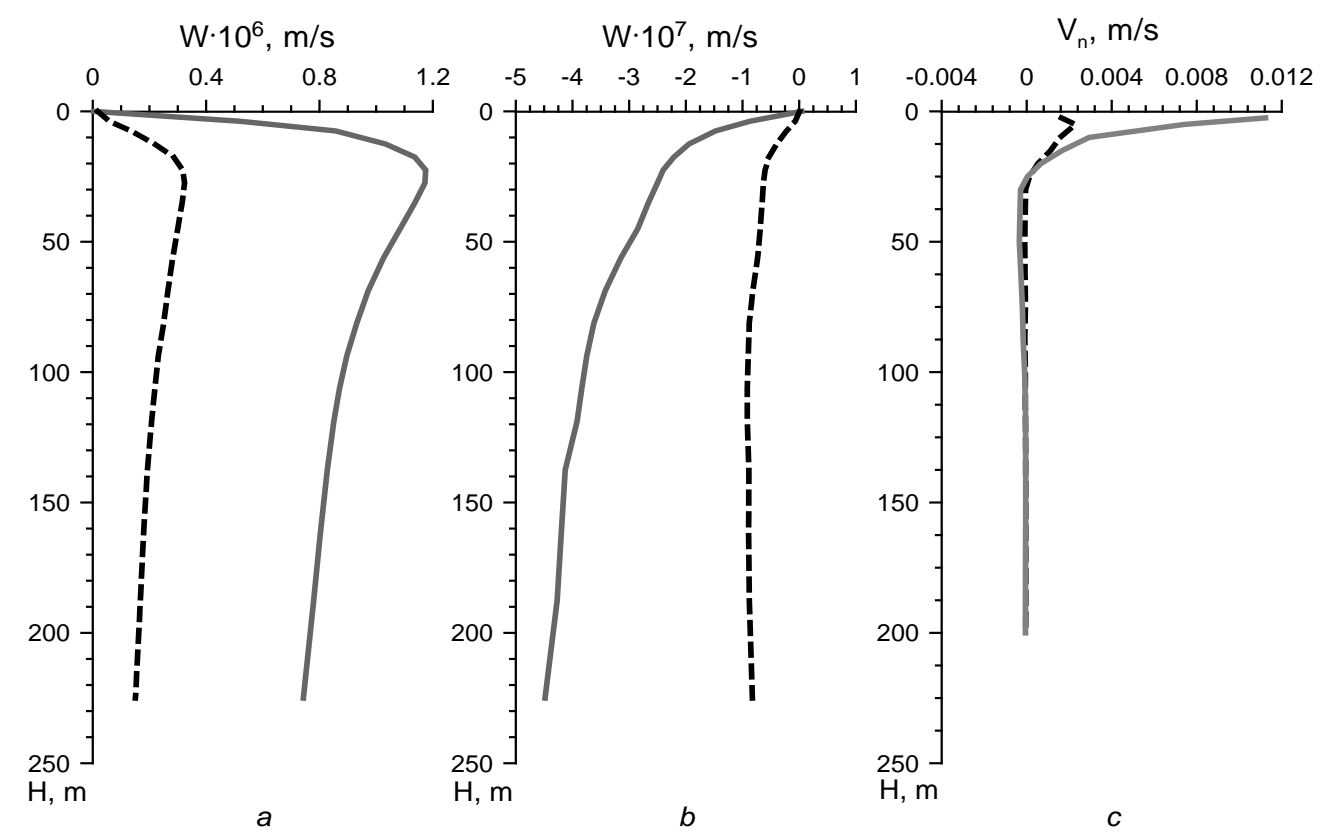

Fig. 9. Profiles of vertical velocity $W$ averaged over the entire considering time period within the area bounded by $1000 \mathrm{~m}$ isobaths $-a$, and out of this area $-b$, as well as profiles of velocity mean values which are normal to the side surface of cylinder bounded by $1000 \mathrm{~m}$ isobaths $-c$ (dashed lines correspond to C1 computation, solid ones - to C2)

It is evident in the graphs in Fig. 9, $a, b$ that in the deep part of the basin the water, on average, rises and in coastal area the water gets down in accordance with the scheme described above. Besides, vertical velocities obtained in C2 computation are several times higher than in $\mathrm{C} 1$ (the maximum values of vertical velocity differ approximately three times). In the both cases in the central part mean vertical velocity increases up to $\sim 25 \mathrm{~m}$ depth and at the sea surface it decreases almost to zero. Vertical velocity increase in up to $25 \mathrm{~m}$ layer must be accompanied with the water inflow through the lateral boundary of the cylinder (its base is bounded by $1000 \mathrm{~m}$ isobaths), and in the upper layer (from 25 to $0 \mathrm{~m}$ ) where vertical velocity decreases the water should flow out through the lateral boundary of this area. Such behavior is confirmed by the profiles of mean values of velocities which are normal to the cylinder side surface depicted in the graph in Fig. 9, c. These profiles were obtained using the fields of current velocity horizontal components from C1 and C2 reanalyzes. According to the behavior of vertical velocity profiles, the direction of mass flow which gets through the side surface in upper layer changes from negative (i.e. inside the deep part) to positive. Horizontal velocity values in C2 data are higher, as well as the vertical velocity values, at that.

The maxima at the vertical velocity component profiles in the deep part of the see are related to the velocity on the lower boundary of Ekman boundary layer which is found through the wind field vorticity: $W_{E}=\operatorname{rot}_{z} \tau /(\rho f)$, where $\tau$ is wind stress; $f$ is Coriolis parameter; $\rho$ is sea water density. Using wind parameter 
values applied in the reanalyzes we are able to obtain mean velocity values $W_{E}$ by this formula for both reanalyzes under consideration. Interannual variability of mean values of vertical velocity component maximum in deep part of the sea is given in Fig. 10 in the form of two graphs for C1 and C2. Ekman velocity $W_{E}$ obtained by wind stress fields (which were used in the reanalyzes) are marked by icons in the same figure. $W_{E}$ values are rather close to the corresponding values of vertical velocity maxima according to calculation results. This correspondence is especially evident for C1 computation. Thus, identification of vertical velocity maximum at the profiles for deep part of the sea with Ekman velocities, which were obtained by the wind fields, looks quite proved. Correspondingly, the depths of these maxima can be identified with the ones of the Ekman layer in both computations. So we may conclude that in both cases wind effect makes the main contribution to the formation of vertical circulation cell in the Black Sea upper layer.

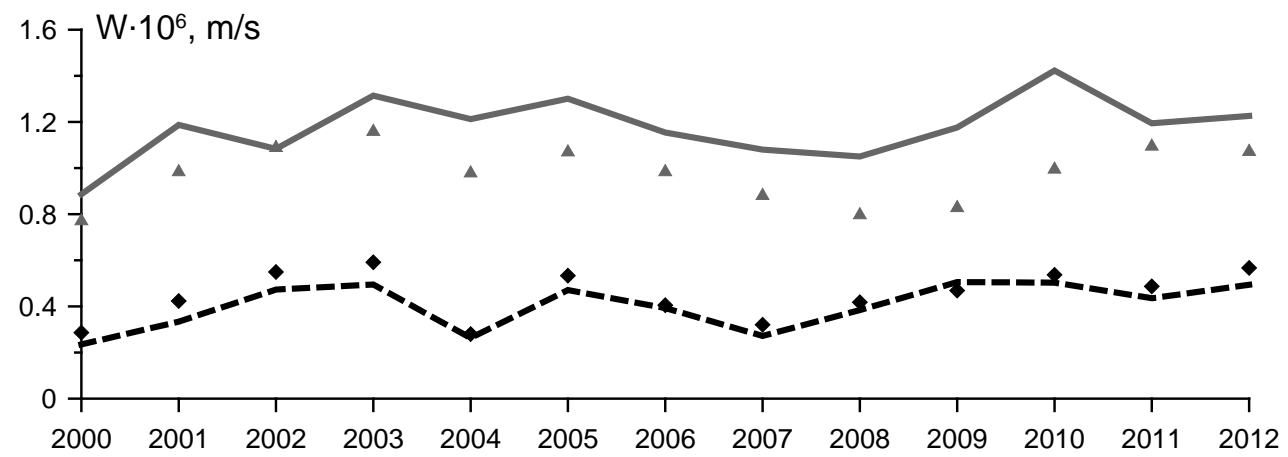

Fig. 10. Variation of vertical velocity $W$ year average value maxima for $2000-2012$ period and corresponding values of Ekman velocity calculated by wind stress (dashed line and triangles correspond to C1 computation, solid line and triangles - to C2 one)

The difference in vertical circulation intensity provides a new way for explaining the differences of salinity fields under consideration: the water in nearsurface layer is more salty according to C2 reanalysis than according to C1 one (Fig. 5). Despite the fact that in general fresh water flux from the sea is greater for C2 computation (and this could explain higher surficial salinity), the phases of fresh water flux and salinity fluctuations at the sea surface do not coincide and sometimes they are in antiphase. Such behavior is due to the difference of vertical velocities. In the center of the basin the upwelling of more salty water takes place, and in the periphery, where the water is fresher due to river runoff, it gets down. The graph that represents the evolution of mean salinity difference in the upper 30 m layer (Fig. 5, b) is given in Fig. 11. In the same figure the evolution of vertical velocity averaged over the season at $30 \mathrm{~m}$ horizon is depicted. It is obvious that both graphs correlate with each other well. On this basis we are able to conclude that surficial salinity difference is caused mainly by vertical circulation difference which, in its turn, is caused by the difference in wind stress vorticity. 


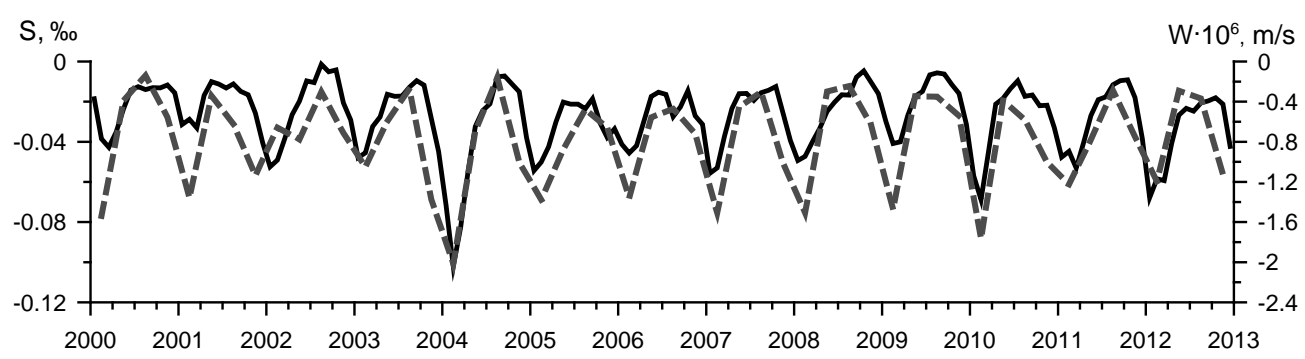

Fig. 11. Evolution of monthly mean salinity difference (P1 - P2) averaged over the basin area in 0 $30 \mathrm{~m}$ (solid line) and vertical velocity difference in a deep part of the sea at $30 \mathrm{~m}$ horizon (dashed line).

Conclusion. This work presents the results of comparison of two Black Sea hydrophysical field reanalyzes carried out on the basis of remote sensing data assimilation. In both cases the same hydrodynamic model and data sets for assimilation were applied. Only atmospheric fields used in the hydrodynamic model as boundary conditions on the free sea surface were different. In fact, it was researched sensitivity of the reanalysis results to atmospheric forcing. Comparative analysis revealed the fact that the results of two computations are relatively close to each other. It means that the weight of data which were assimilated in the obtained results is quite high. At the same time, the differences caused by different atmospheric effect fields are observed.

The temperature in near-surface layer is higher for most part of the year according to C1 reanalysis. This is caused by corresponding of heat flux difference at the sea surface in atmospheric data. In $30-100$ layer mean temperature is always higher according to $\mathrm{C} 2$ results. Apparently, this is due to the fact that in winter negative heat flux on the surface is greater (in absolute value) for ERAInterim fields. For this reason according to $\mathrm{C} 1$ computation surface waters cool down more rapidly, therefore convection processes are more intensive in this case. Consequently, the process of CIL water refreshment is more intense. It should be pointed out that in winter SST satellite data gaps are the greatest, therefore heat flux effect on temperature formation in model calculation increases at this time.

The Black Sea surface water circulation in each case under consideration is rather close to each other. At the same time, the values of mean kinetic energies of currents have some differences. The currents are more intensive according to C2 computation, especially for the time scales shorter than a month. Kinetic energy differences of currents averaged over the month are mainly determined by wind shear field vorticity difference. Apparently, for the currents with smaller scale this difference is caused by better spatial-temporal resolution of $M M 5$ fields.

Parameters of mean vertical circulation in upper $200 \mathrm{~m}$ layer were calculated by the results of two reanalyzes. Vertical velocity in the deep part of the basin appeared to be significantly higher according to C2 computation. This was caused by higher value of mean wind vorticity over this part of the sea. Due to this a far more intensive salt water rise to the surface in the center of the basin and a sink of more fresh waters in the periphery take place. As a result, the water in subsurface sea layer is more salty according to C2 reanalysis data. Thus, wind field vorticity 
difference has more effect on salinity difference in subsurface layer, not the difference of fresh water fluxes through the free surface.

Acknowledgements. The work was performed within the framework of scientific project "Research of regularities of changes in the state of the marine environment on the basis of operational observations and data of the nowcast, forecast, and reanalysis of state of the sea areas system" (Operational Oceanography code).

The authors are grateful to M.V. Shokurov for providing $M M 5$ atmospheric fields.

\section{REFERENCES}

1. Knysh, V.V., Korotaev, G.K. \& Moiseenko, V.A. [et al.], 2011, “Sezonnaya i mezhgodovaya izmenchivost' gidrofizicheskikh poley Chernogo morya, vosstanovlennykh na osnove reanaliza za period 1971 - 1993 [Seasonal and interannual variability of Black Sea hydrophysical fields reconstructed from 1971-1993 reanalysis data]”, Izv. RAN. Fizika atmosfery i okeana, vol. 47, no. 3, pp. 433-446 (in Russian).

2. Knysh, V.V., Kubryakov, A.I. \& Moiseenko, V.A. [et. al], 2008, “Tendentsii v izmenchivosti termokhalinnykh i dinamicheskikh kharakteristik Chernogo morya, vydelennye po rezul'tatam reanaliza za period 1985-1994 [Trends in the Black Sea thermohaline and dynamic variability defined by the results of reanalysis for 1985-1994 period]", Ekologicheskaya bezopasnost' pribrezhnoy i shel'fovoy zon i kompleksnoe ispol'zovanie resursov shel'fa, iss. 16, pp. 279-290 (in Russian).

3. Knysh, V.V., Korotaev, G.K. \& Mizyuk, A.I. [et al.], 2012, “Usvoenie gidrologicheskikh nablyudeniy dlya rascheta techeniy $v$ moryakh $i$ okeanakh [Assimilation of hydrological observation data for calculating currents in seas and oceans]", Ekologicheskaya bezopasnost' pribrezhnoy i shel'fovoy zon i kompleksnoe ispol'zovanie resursov shel'fa, vol. 48, no. 1, pp. 67-85 (in Russian).

4. $\quad$ Dorofeev, V.L., Sukhikh, L.I., 2016, “Analiz izmenchivosti gidrofizicheskikh poley Chernogo morya v period 1993-2012 godov na osnove rezul'tatov vypolnennogo reanaliza [Analysis of Variability of the Black Sea Hydrophysical Fields in 1993 - 2012 Based on the Reanalysis Result]”, Morskoy gidrofizicheskiy zhurnal, no. 1, pp. 33-48 (in Russian).

5. Demyshev, S.G., Korotaev, G.K., 1992, "Chislennaya energosbalansirovannaya model' baroklinnykh techeniy okeana s nerovnym dnom na setke $C$ [Numerical energy-balanced model of baroclinic currents in the ocean with bottom topography on the C-grid]", Chislennye modeli i rezul'taty kalibrovochnykh raschetov techeniy v Atlanticheskom okeane, pp. 163-231 (in Russian).

6. Korotaev, G.K., Oguz, T. \& Dorofeyev, V.L. [et al.], 2011, "Development of Black Sea nowcasting and forecasting system”, Ocean Sci., vol. 7, no. 5, pp. 1-21.

7. Shokurov, M.V., 2011, "Chislennoe modelirovanie atmosfernoy tsirkulyatsii nad Chernym morem [Numerical simulation of atmospheric circulation over the Black Sea]", Ekologicheskaya bezopasnost' pribrezhnoy i shel'fovoy zon i kompleksnoe ispol'zovanie resursov shel'fa, iss. 25, vol. 2, pp. 91-113 (in Russian). 
8. Dorofeev, V.L., 2004, “Assimilyatsiya sputnikovykh izmereniy poverkhnostnoy temperatury Chernogo morya $v$ modeli tsirkulyatsii [Assimilation of remote sensings of the Black Sea surface temperature in the circulation model]", Ekologicheskaya bezopasnost' pribrezhnoy i shel'fovoy zon i kompleksnoe ispol'zovanie resursov shel'fa, iss. 11, pp. 24-30 (in Russian).

9. Korotaev, G.K., Saenko, O.A. \& Koblinskiy, Ch.Zh. [et. al.], 1998, “Tochnost', metodologiya i nekotorye rezul'taty assimilyatsii al'timetricheskikh dannykh TOPEX/POSEIDON v modeli obshchey tsirkulyatsii Chernogo morya [Accuracy, methodology and some results of TOPEX/POSEIDON altimetry data assimilation in the model of the Black Sea general circulation]”, Issledovanie Zemli iz kosmosa, no. 3, pp. 3-17 (in Russian).

10. Dorofeev, V.L., Korotaev, G.K., 2004, “Assimilyatsiya dannykh sputnikovoy al'timetrii v vikhrerazreshayushchey modeli tsirkulyatsii Chernogo morya [Assimilation of the satellite altimetry data in the eddy resolved model of the Black Sea circulation]”, Morskoy gidrofizicheskiy zhurnal, no. 1, pp. 52-68 (in Russian).

11. Gertman, I.F., 1991, "Termokhalinnaya struktura vod morya [The thermohaline structure of the sea waters]”, Gidrometeorologiya i gidrokhimiya morey SSSR. T. IV. Chernoe more. Vyp. 1. Gidrometeorologicheskie usloviya, vol. 4, iss. 1, pp. 146-195 (in Russian).

12. Ovchinnikov, I.M., Popov, Yu.I., 1984, “ $K$ voprosu o formirovanii kholodnogo promezhutochnogo sloya $v$ Chernom more [On the formation of the cold intermediate layer in the Black Sea]”, Dokl. AN SSSR, vol. 279, no. 4, pp. 986-989 (in Russian).

13. Blatov, A.S., Bulgakov, N.P. \& Ivanov, A.N., [et al.], 1984, “Izmenchivost' gidrofizicheskikh poley Chernogo morya [Variability of the hydrodynamical fields in the Black Sea]", Saint Petersburg, Gidrometeoizdat, 240 p. (in Russian).

14. Oguz, T., Besiktepe, S., 1999, “Observations on the Rim Current structure, CIW formation and transport in the western Black Sea”, Deep-Sea Res., vol. 46, no. 10, pp. 1733-1753.

15. Korotaev, G., Oguz, T. \& Nikiforov, A. [et al.], 2003, “Seasonal, interannual, and mesoscale variability of the Black Sea upper layer circulation derived from altimeter data”, J. Geophys. Res., vol. 108, no. C4, 3122, pp. 1-15.

16. Zhurbas, V.M., Zatsepin, A.G. \& Grigor'eva, Yu.V. [et. al], 2003, “Tsirkulyatsiya vod i kharakteristiki raznomasshtabnykh techeniy v verkhnem sloe Chernogo morya po drifternym dannym [Circulation of waters and characteristics of different-scale currents in the Black Sea upper layer according to drifter data]”, Okeanologiya, vol. 43, no. 6, pp. 1-15 (in Russian). 